\begin{tabular}{cc} 
Revista de & Journal of Integrated \\
GESTÃO COSTEIRA Integrada COSTAL ZONE MANAGEMENT \\
\hline
\end{tabular}

\title{
Water quality along the Alagoas State Coast, Northeast Brazil: advocacy for the coastal management
}

\author{
Thiago Henriques Fontenelle, ${ }^{1}$; José Antonio Baptista Neto ${ }^{\mathrm{a}}$, Estefan Monteiro da Fonseca ${ }^{\mathrm{a}}$ @
}

\begin{abstract}
Poorly planned urban development and the associated lack of sanitation infrastructure are the main causes of ecosystem alteration and contamination of Alagoas coastal zone. As these ecosystems are significantly linked with human use, such as recreation and tourism, the impacts on human health cannot be obviated. The present study evaluates the water quality of the Alagoas coastal zone analyzing five years of monitoring data obtained from the state Environment Office. Results suggest a worsening of the water quality between the years 2007-2011. Low levels of sanitation, especially sewage collection and treatment, the lack of an effective land planning, environmental development of agribusiness activities and low perceptions of sustainability appear to be the main factors impacting the water quality of the Alagoas state coast. On the other hand, investment in sanitation has boosted investor confidence and driven development, to the extent that sanitation infrastructure capacities have been exceeded and raises potential water quality issues.
\end{abstract}

Keywords: Sanitation infrastructure, domestic sewage, tourism impact, land planning, pollution.

\section{Resumo}

\section{A qualidade da água ao longo do Estado Alagoas Coast, Nordeste do Brasil: a defesa da gestão costeira}

A contaminação da zona costeira resultante do desenvolvimento urbano mal planejado é uma das principais causas da alteração dos ecossistemas, com efeitos sobre a saúde humana. O presente estudo estabelece um diagnóstico da zona costeira de alagoas, avaliando cinco anos de dados de monitoramento obtidos da secretaria de meio ambiente local. Os resultados sugerem a piora ao longo dos anos (2007-2011). Baixos níveis de saneamento, especialmente coleta e tratamento de esgoto, a falta de um planejamento urbano efetivo, o desenvolvimento das atividades do setor agrícola parecem ser os principais fatores impactantes da qualidade das águas da costa do estado de Alagoas. Por outro lado, em Barra de São Miguel, os investimentos em saneamento melhoraram as condições ambientais, incrementando ainda mais o turismo e a expansão urbana,o que sobrecarrega a própria infraestrutura sanitária existente.

Keywords: Infra-estrutura de saneamento, esgotos domésticos, impacto do turismo, ordenamento de território, poluição

\footnotetext{
(a) Corresponding author, to whom correspondence should be addressed.

${ }^{1}$ Universidade Federal Fluminense, Instituto de Geociências, Departamento de Geologia e Geofísica, Av. General Milton Tavares de Souza, Niterói, RJ, Brasil. E-mails: Fontenelle <uff.thiago@gmail.com>; Neto <jabneto@id.uff.br>; Fonseca <oceano25@hotmail.com>
}

* Submission: 24 OCT 2014; Peer review: 28 NOV 2014; Revised: 25 MAR 2015; Accepted: 5 MAY 2015; Available on-line: 6 MAY 2015

This article contains supporting information online at http://www.aprh.pt/rgci/pdf/rgci-562_Fontenelle_Supporting-Information.pdf
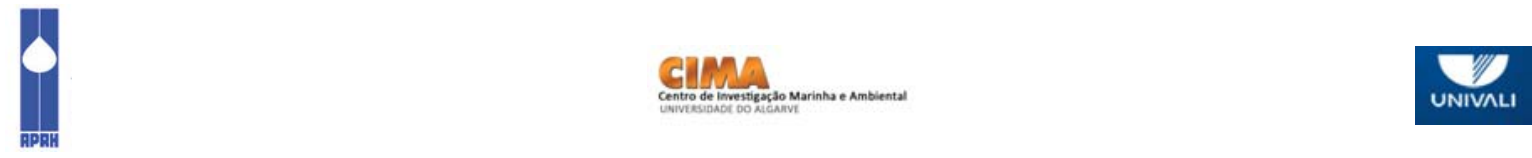


\section{Introduction}

Coastal environments contain some of the marine world's most important ecosystems and represent significant resources for human industry and recreation. The biological richness of coastal ecosystems is widely recognized, and makes them attractive areas for the establishment and development of human communities worldwide: Approximately $60 \%$ of whom are found in coastal areas (Constanza et al., 1997). Currently, 24.6\% of Brazil's population lives in coastal counties, accounting for $4.1 \%$ of the total area of the country (IBGE, 2011a).

This impact of population concentration and the development of various economic activities on coastal ecosystems are remarkable due to the poor environmental and territorial planning and the lack of infrastructure, especially sanitation. In addition to its resident population, its tropical climate and beautiful landscapes makes Brazil's coast attractive for tourism. According to the Ministry of Tourism, in 2012, Brazil received 5.67 million international tourists arrivals, - mostly from South America (2.63 million), Europe (1.62 million) and U.S. (0.59 million) (MT, 2013). However, domestic tourism is significant in Brazil, and has been driven by rising real incomes and a growing middle class. In 2012, domestic landings totaled 85.47 million, as opposed to 43.1 million in 2005 (MT, 2013), suggesting a phenomenal growth in the industry. This situation has generated great pressure on coastal ecosystems resulting in a decrease in water quality and biodiversity, loss of critical habitats, and an overall decrease in the health and quality of life of local inhabitants (MMA, 2005). The impact of population concentration, a growing tourism sector and the development of various economic activities on Brazil's coastal ecosystems are occurring within a milieu of poor environmental and territorial planning for infrastructure, especially sanitation.

Water quality is a major environmental health indicator, reflecting the interference of human activities both in the coastal zone and in the adjacent catchments. Expressed as bathing (in the present study), it refers to the quality of water for the purpose of primary contact recreation, i.e. direct and prolonged contact with water, with high probability of ingestion, as in activities of swimming, diving and some other water sports (MMA, 2005).

The bathing measures adopt microorganisms commonly present in stool, as an indicator of the level of contamination by sewage. The presence of pathogenic organisms is not assessed directly due to the large number and variety of these individuals (Noble et al., 2003), associated with varying densities, sources and levels of risk that they present, which technically and financially impracticable for a systematic environmental monitoring. However, the improper bathing condition class indicates a high likelihood of pathogens, and therefore risks to public health. Brazilian law establishes standards for bathing for three groups of organisms: fecal coliforms, Escherichia coli and Enterococci (MMA, 2001).

Thus, this paper analyzes the beach bathing conditions in the state of Alagoas, northeastern Brazil, between 2007 and 2011, using an annual rate of bathing from the standards set by law (MMA, 2004).

\section{Studied area}

The study was carried out on the coast of Alagoas, which stretches for about $230 \mathrm{~km}\left(8^{\circ} 55^{\prime} \mathrm{S}-36^{\circ} 10^{\prime} \mathrm{W}\right.$ and $10^{\circ} 30^{\prime} \mathrm{S}-36^{\circ} 23^{\prime} \mathrm{W}$ respectively) (Figure 1), and is composed mainly of coral and sandstone reefs, lagoons, rivers and mangrove ecosystems. Alagoas is one of the nine states of northeastern Brazil. It is subdivided into 102 municipalities and had a total population of $3,120,494$ in $2010,73.6 \%$ of which living in urban areas (IBGE, 2011b; IBGE,2011c). Maceió is the capital, with 933,000 inhabitants $(30 \%$ of total State population), and is home to $40.6 \%$ of its urban population.

According to Brazilian law, the coastal zone is divided into two tracks: the sea, which corresponds to the territorial sea (12 nautical miles from the baseline of the coast), and the land, which is the band formed by areas of the continent suffering direct influence of coastal phenomena (MMA, 2004). In Alagoas, 23 municipalities met one of eight legal criteria that classify them as members of the land strip (IBGE, 2011a).

The main factors of potential negative impact on the quality of coastal waters of Alagoas are: cattle and cultivation of sugar-cane associated with deforestation, and lack of territorial-environmental planning and environmental sanitation infrastructure associated with the tourism (IBGE, 2011a).

The sugar cane production area is concentrated in the municipalities near the coast, having corresponding, in 2011, 29.9 million tons in a planted area of 435,000 hectares (IBGE, 2011a). The supply chain is related to the 25 sugar cane mills currently installed in the area (UDOP, 2012). This cultivation is mainly responsible for the strong deforestation in the Atlantic Forest region (Verdade et al., 2012). With regard to environmental sanitation, only $26.6 \%$ of the population of coastal counties have sewage collection network for general or rain, while $65.8 \%$ use septic tanks $(16.6 \%$ and $49.2 \%$ rudimentary septic) (IBGE, 2011b). Even in areas of collection, most of the sewage does not undergo treatment.

\section{Material and methods}

The main effect of the impacts on the water quality caused by the increasing human settlements near the coastal areas is the presence of pathogenic microorgan- 

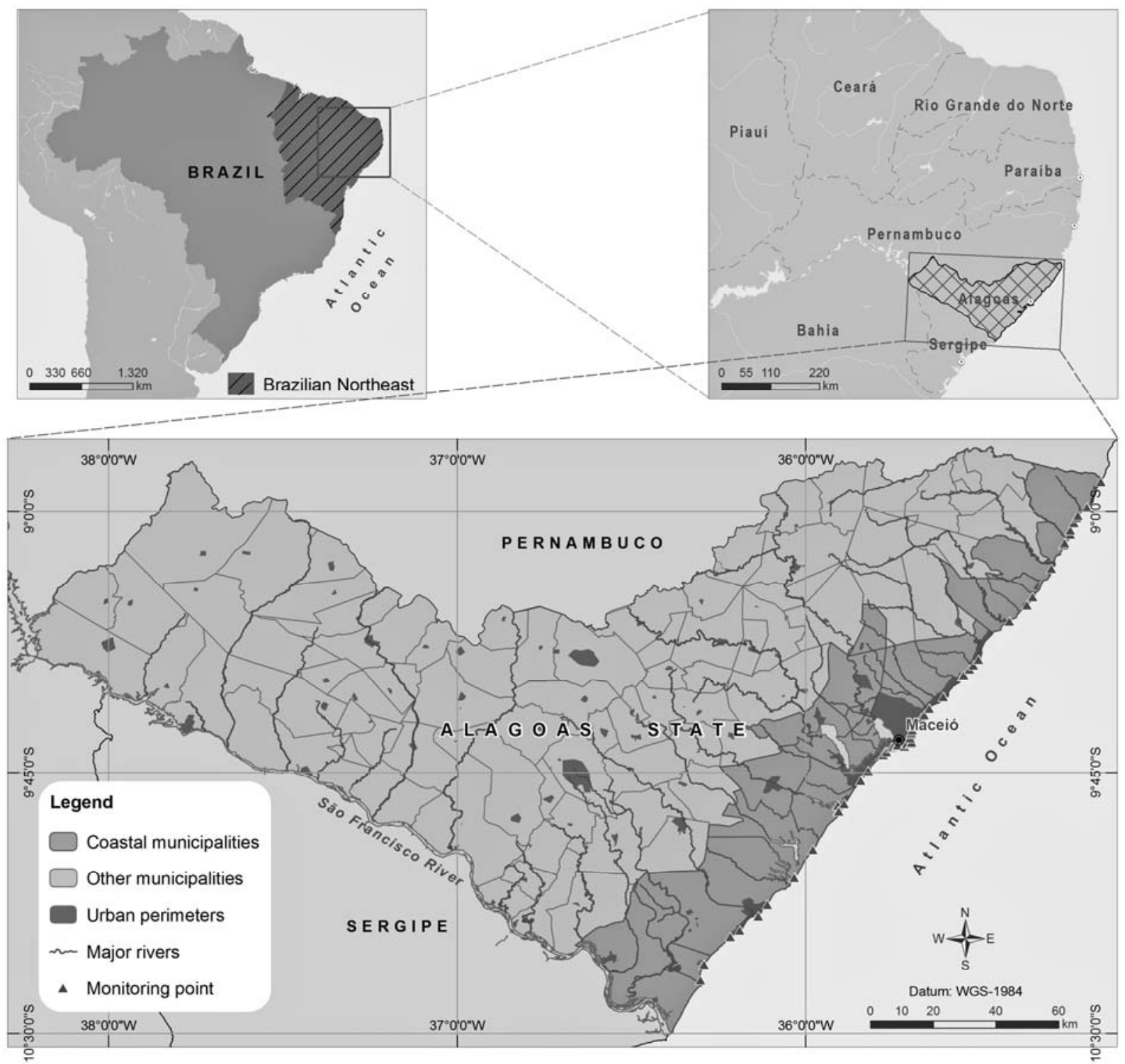

Figure 1- Study Área

Figura 1- Área de estudo

isms (Ramaiah, 2002) in coastal waters. Presence of fecal coliform bacteria, especially E. coli (Guan et al., 2002), has shown strong correlation to swimming associated illnesses (Uzoigwe et al., 2007). As fecal contamination and higher incidence of pathogens are reported in literature (Fujioka, 2002; Wilkes et al., 2009), it is essential for collating the abundance of certain known human pathogenic bacteria along with the enumeration of coliforms. Based on this information, the coastal water quality in the Alagoas State was evaluated using thermotolerant coliform (fecal) as indicator, in 53 stations (Figure 2) monitored weekly by the Environmental Institute of the State of Alagoas. The data for the analysis captured a period of five years (February 2007 to December 2011).

The methodology of sampling and analysis was based on the 20th Edition of Standard Methods for the Examination of Water and Wastewater (APHAAWWA-WPCF, 1999).
In the present study, a total of 250 reports were analyzed with more than 11,000 tested samples (IMA/AL, 2012). The results were digitized and integrated into a database and geographical information systems. Each sample was rated weekly for bathing according to the limits established by the Brazilian legislation, which is based on the last five consecutive weeks sampled (MMA, 2005) (Table 1). Based on this classification, the annual rate of bathing for each monitoring station using the index developed by CETESB (2012) (Table 2) were calculated.

Systematic monitoring of water quality data allows for the identification of trends that can be used in the coastal planning and management, as well as to improve monitoring effectiveness in the environmental change. In this study, seasonal effect was evaluated by both, the evolution of the annual rate of bathing (IAB) and the statistical test of Mann-Kendall. In the latter case, two annual average concentrations of fecal coli- 


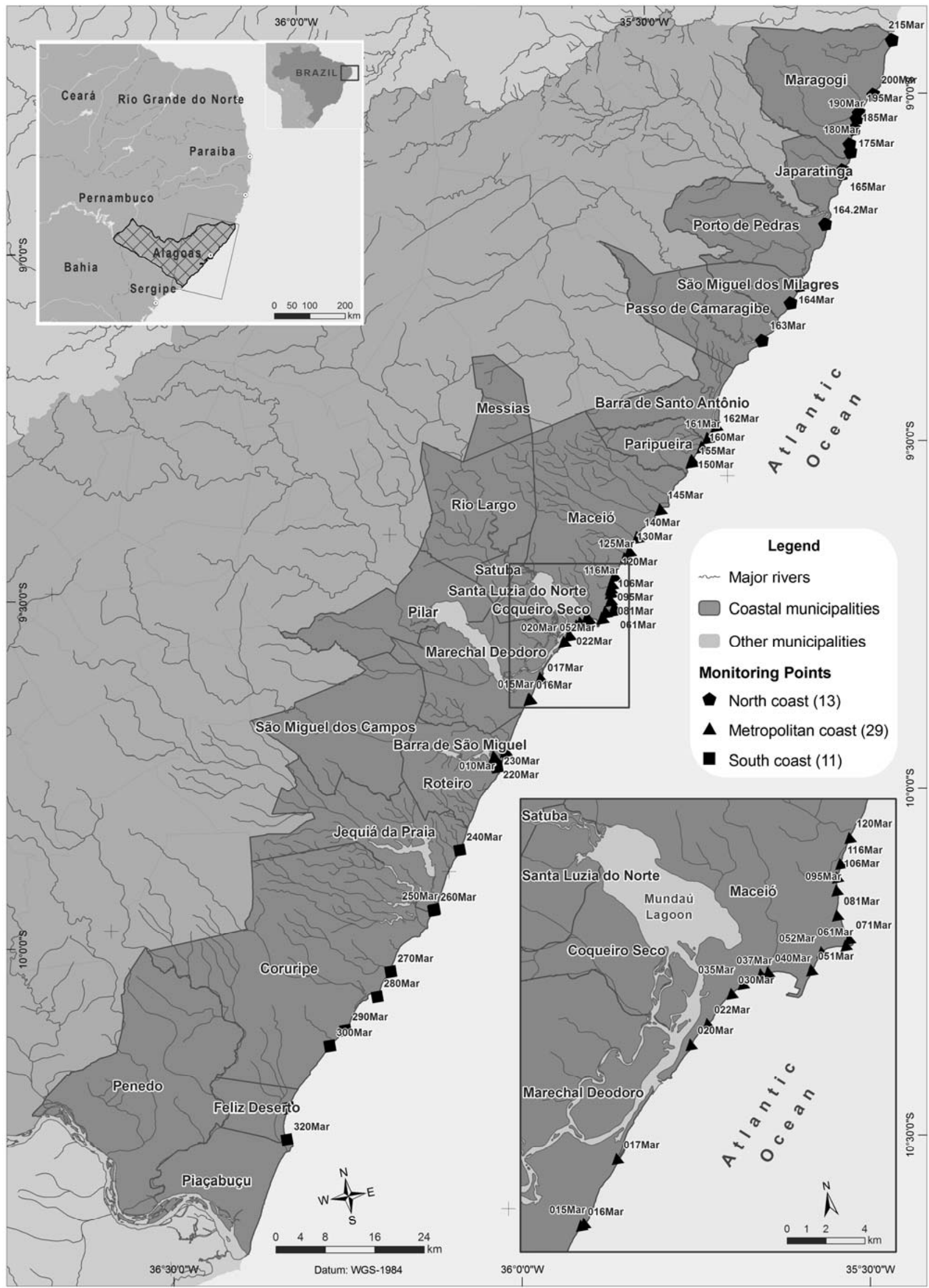

Figure 2- Sampling Stations.

Figura 2- Estações de Coleta. 
Table 1 - Criteria for bathing classification according to Brazilian legislation.

Tabela 1 - Critérios para classificação da balneabilidade de acordo com a legislação brasileira.

\begin{tabular}{c|c|c}
\hline \multicolumn{2}{c|}{ CATEGORY } & Fecal Coliforms (NMP/100 mL) \\
\hline \multirow{3}{*}{ SUITABLE } & Excellent & $\leq 250$ in at least $80 \%$ of the time or more \\
\cline { 2 - 3 } & Very good & $\leq 500$ in $80 \%$ of the time or more \\
\cline { 2 - 3 } & Satisfactory & $\leq 1.000$ in $80 \%$ of the time or more \\
\hline \multirow{2}{*}{ UNSUITABLE } & $>1.000$ in $20 \%$ of the time or more \\
\cline { 2 - 2 } & $>2.500$ measurement \\
\hline
\end{tabular}

Table 2 - Criteria for calculating the annual index of bathing (IAB)

Tabela 2 - Critério para o cálculo do índice anual de balneabilidade

\begin{tabular}{c|l}
\hline CLASS (BI) & \multicolumn{1}{c}{ Bathing index } \\
\hline EXCELLENT & $\begin{array}{l}\text { Beaches classified as EXCELLENT in } \\
100 \% \text { of the time }\end{array}$ \\
\hline GOOD & $\begin{array}{l}\text { Beaches classified as PROPER 100\% of } \\
\text { the time, except when EXCELLENT }\end{array}$ \\
\hline REGULAR & $\begin{array}{l}\text { Beaches classified as UNSUITABLE 25\% } \\
\text { of the time }\end{array}$ \\
\hline BERY BAD & $\begin{array}{l}\text { Beaches classified as UNSUITABLE } \\
\text { between 25\% and 50\% of the time } \\
\text { beaches classified as UNSUITABLE } \\
\text { between 50\% and 75\% of the time }\end{array}$ \\
\hline CRITICAL & $\begin{array}{l}\text { Beaches classified as UNSUITABLE in } \\
\text { over 75\% of the time }\end{array}$ \\
\hline
\end{tabular}

Modified from CETESB(2012).

forms at each station were seasonally tested, subdivided in the rainy (March to September) and dry season (January-February and October-December) using Water Quality Analyzer 2.1.2.4. (Water Quality Analyser, 2011)

It is important to highlight, for the presentation and discussion of the results, that the Alagoas coastline were subdivided into three compartments (IMA/AL, 2012): north coast, metropolitan coast (or central) and south coast. This subdivision was proposed by Muehe (2006) based on geological and geomorphological macro context and limitations of the major watersheds.

\section{Results and discussion}

The results suggest high levels of improper bathing on the beaches of Alagoas, especially in the northern and metropolitan compartments. Over the five years analyzed (2007-2011), 37.9\% of the samples of the north coast and $33.7 \%$ of the samples from metropolitan coast, showed the classification of bathing over the legal limit allowed for primary contact recreation (Figure 3). In annual change, there is relative stability of average rates of improper between 2007 and 2010, and an increase in the last year - 2011.

The north coast showed an average annual improper between $33.1 \%$ and $46.6 \%$ of the weekly analyzed samples, in the 13 stations. The metropolitan coast showed averages of improper between $29.1 \%$ and $38.4 \%$ in its 29 stations, while the southern coast showed the best aggregate result, averaging between $0.5 \%$ and $7.7 \%$ of improper in 11 monitored stations. The lowest levels of improper occurred in 2010, in the middle compartments, which coincide with the year of less rain (precipitation less than 10-20\% compared with the period of 2007-2011) (Figure 4).

In the capital, Maceió, with extensive coastlines and higher density of monitored station (19) (Figure 2), the annual average of improper class ranged from $38.0 \%$ (2009) and 51.5\% (2011), and the average of the period 2007 to $2011,44.6 \%$ of the stations. Several surveys have studied (Neto et al, 2002; Santos Filho et al., 2007) the watersheds that supply the city and flow to its coastline and therefore likely to have a direct relationship with the quality of the coastal waters of the region. According to Santos Filho et al. (2007) Riacho do Silva catchment, for example, is fully inserted in the urban city of Maceió, is a system rich in water resources, native flora and fauna. Some authors carried out in the catchment show the environmental degradation resulting from the human activity (Santos Filho et al., 2007). On the other hand, Silva Júnior (2009) pointed out to the disorderly occupation of watersheds such as catchment Riacho Reginaldo also in Maceió, as a cause of increased soil impermeability, which increased runoff dynamics, hence up the contribution of contaminants in the coastal zone. Some authors describe the Maceio region as a major industrial concentration where companies do not treat their effluents which goes directly to 
sinks similar to systems used in sewage lagoons region or to the accumulation of rainwater (Neto et al., 2002).

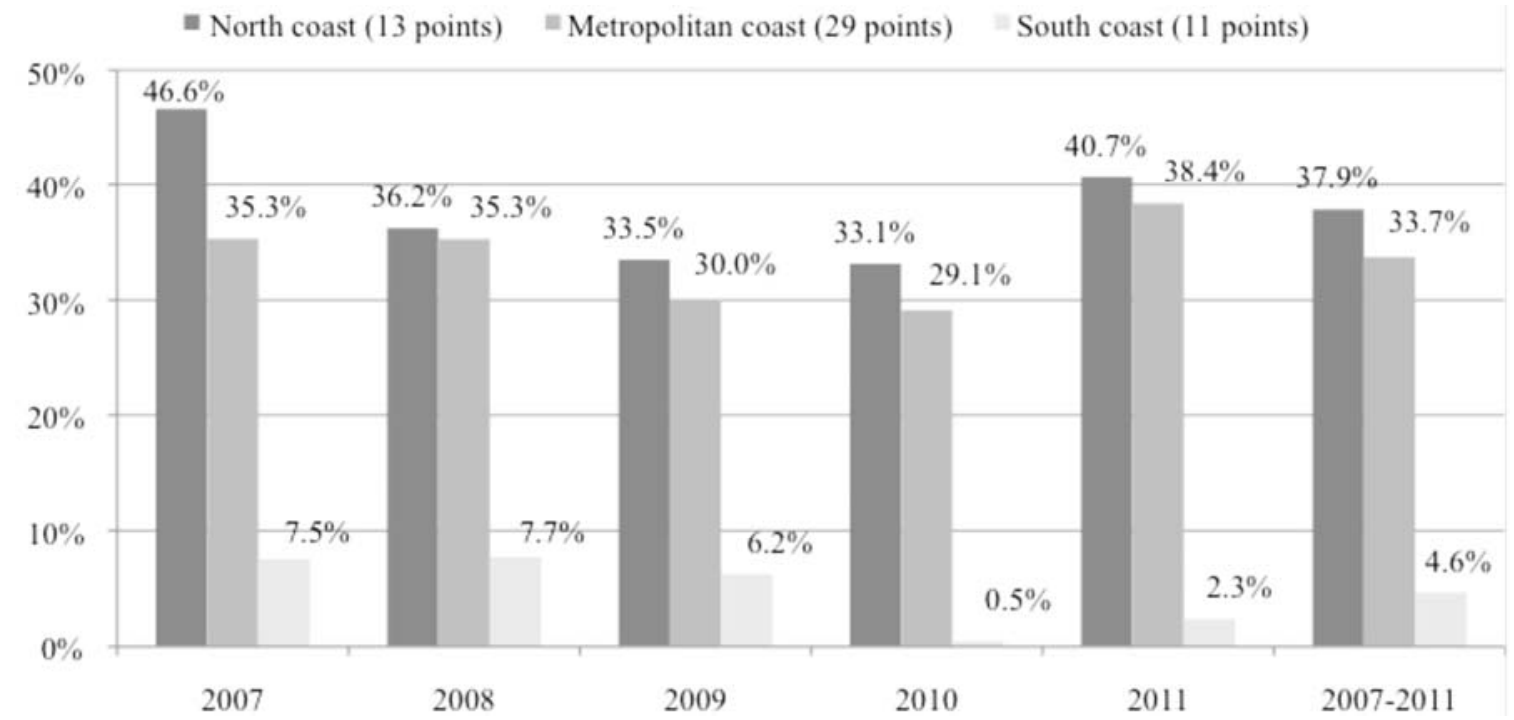

Figure 3 - Annual average (2007-2011) of improper bathing (\%) per compartment.

Figura 3 - Média Anual (2007-2011) de balneabilidade imprópria (\%) por compartimento.

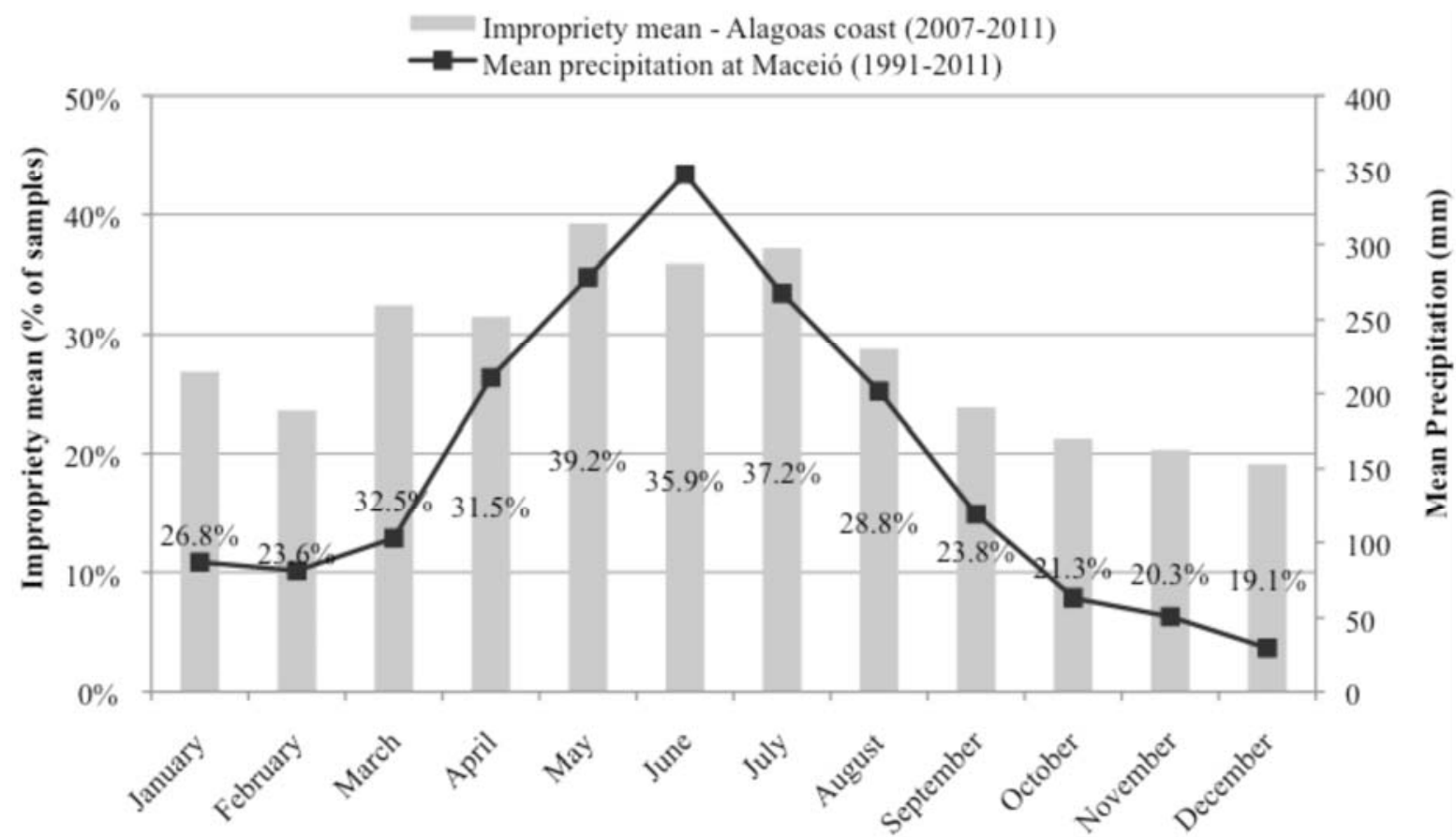

Figure 4 - Mean impropriety in the Alagoa's littoral and mean precipitation in the Maceió.

Figura 4 - Média na balneabilidade imprópria no litoral de Alagoas e média da precipitação em Maceió.

The annual ranking of each monitoring stations in the state of Alagoas is presented in Supporting Infomation, as well as the outcome of the seasonal differences.

The north coast, between the stations of Japaratinga Beach (165Mar) and Maragogi Beach (215Mar) the situation is especially worrying due to the high incidence of impropriety, ranging from regular and $\mathrm{bad} /$ critical, being critical or poor in five years in three stations (Figure 2). In south-central coast of Maceió, in the 14 stations between the Pontal da Barra (020Mar) and Jacarecica Beach (Sea 120) the situation is even more serious, with many bad stations, bad or critical and five stations always bad or critical in the period of 2007 to 2011 ( $>50 \%$ of improper, reaching $100 \%$ of impropriety (Figure 2 and Supporting Information). Melo-Magalhães et al. (2009) studied the phytoplankton communities of Mundaú Mangaba coastal lagoons, responsible for the continental runoff to the nearest stations of the Pontal da Barra. The results 
obtained in Mundaú and Manguaba lagoons characterized the two lagoons as strongly impacted environments. The area is also known for frequently

cyanobacterial blooms resulting from the domestic input originated in the vicinity of the lagoons (Porfirio et al., 1999; Oliveira \& Kjerve, 1993) beyond the supply of tailings from the sugar cane production (Oliveira and Kjerve, 1993 ).

In general, there is relative stability in the classification of the stations between 2007 and 2011. Small track variations can be considered normal due to the conditions of sample collection. For example, the occurrence of rain in the last 24 hours. However, abrupt changes in the midst of a large set of samples suggest effective situations of improvement or worsening of water quality.

Among the areas with improved Bathing Index (IAB), it is noteworthy the south coast, with generally positive trend, reaching at most stations classes of good or excellent in 2011, which means $100 \%$ of the water property in the analyzed weeks. The station on the Coruripe Pontal (280Mar) showed the most significant improvement, starting with poor condition in 2007 , becoming regular in 2008 and 2009 and reaching a good class in the last two years analyzed.

Metropolitan coastline, Praia da Barra de São Miguel (010Mar) also improved, going from regular status in three consecutive years (2007-2009) to good in 2010 and 2011, (100\% of bathing conditions in the accordance with the Brazilian law - see Figure 2 and Supporting Information). The significant improvement is linked to the progress of sanitation in Barra de São Miguel (7,574 inhabitants) (IMA/AL, 2012), with a focus on remediation of Niquim River, which input into the ocean and was the main destination of sewage and garbage from residents.

The example of Barra de Sao Miguel highlights the benefits of investing in sanitation. The improvement of environmental conditions has driven even more tourism and housing developments in the city (MT, 2013), which also put pressure on the sanitation infrastructure. However, the consolidation of urban laws and parameters of spatial planning through the Master Plan approved in 2008 has provided a framework for the planned occupation (IMA/AL, 2012). The demographic and occupational characteristics, as well as the sources of environmental degradation, are very similar to the Barra de São Miguel in several coastal counties of Alagoas, which points to the actual possibility of improving the quality of water in these regions (IMA/AL, 2012).

In relation to the northern metropolitan coastline, the beaches of Paripueira and Barra de Santo Antônio (155Mar the 162Mar) showed trend of worsening annual ranking, since the beaches did not show $100 \%$ of bathing in the last three years. The same occurs with the station 164Mar in São Miguel dos Milagres. It is important to highlight that these stations cited worsened

even in years in which the average quality of the compartment was good.

These three municipalities, with significant points of worsening water quality, present demographic and socioeconomic profile similar to Barra de Sao Miguel with a population ranging between 7,000 and 15,000 inhabitants (IMA/AL, 2012), which reaches three times this size in the high tourism season periods, accompanied by rapid expansion of the occupation (MMA, 2005). However, in these areas there are no necessary investments in the environmental sanitation and urban planning. Barra de Santo Antônio, as an example, experienced a "boom" of sprawl, including the invasion of the land and many areas by low income population derived from more distant counties, resulted by the opening of the bridge that connects the mainland to the island of Crôa, in 2010. It should be noted that none of the three municipalities have municipal master plan approved till the present moment (IMA/AL, 2012).

Trend data through the annual bathing classifying suggests being very effective when rapid changes occur as in points highlighted above. However, it does not appear to be sensitive, to changes that do not result in change of class (eg the increase of coliforms without leaving regular class, or its decrease without leaving the class bad). On the other hand, areas with better water quality index becomes very susceptible to occasional events (eg, at the stations that has always good bathing, a single isolated event, featuring over 1,000 coliforms $\mathrm{NMP} / 100 \mathrm{~mL}$, makes the beach improper in five consecutive weeks). In this sense, and also seeking to incorporate the seasonality of the phenomenon, the statistical trend (TE) emerges as an excellent analytical complement. In areas with significant changes in $\mathrm{TE}$ it showed the same trend based on the annual ranking, as in the case of reductions of coliforms in the south coast and increases between Paripueira and Barra de Santo Antônio (Table 1). In this second case, the TE also revealed worsening of water quality in neighboring stations (116Mar the 150Mar), especially in the dry season. Note that the entire region surrounding the station $116 \mathrm{Mar}$ is absorbing urban sprawl of Maceió and developing accelerated expansion of tourism and urbanization (MT, 2013).

The increasing concentrations of coliforms in the dry season suggest the worsening of the water quality in the northern and metropolitan coastal areas. This result indicates the intensification of point sources of domestic pollution in the period, which includes the festive periods, school holidays and summer, and that, based on the performance of tourism in recent years, implies a considerable increase of the floating population. 
The southern coast, with low urbanization and weak tourism activities (IMA/AL, 2012), showed an improved water quality through data analysis, rating the

results obtained based on the bathing index. Despite the positive results found in the present study, there is a lack of field sanitation (excessive accumulation of garbage and open sewage, for example) and poor spatial planning policy in the cities of the south coast, which slightly affects the quality of coastal waters due to small occupation and tourism.

The monthly basis and seasonal (rainy and dry seasons) data demonstrates the strong correlation between the concentration of fecal coliform in the rainiest months, indicating both the effect of diffuse pollution as well as the intensification of point sources of pollution (Figure 4).

The stations most affected by the rainy season were those with lower water quality and those near the river mouths and urban drainage. The positive correlation between fecal bacteria and precipitation is reported by several authors both in other parts of the world (such as Solo-Gabriele et al., 2000 and Alm et al., 2003) and in the northeastern Brazil (Medeiros, 2009; Morais and Silva,2012).

The results on the Alagoas coast also highlights to the increasing unsuitability in months of strong population growth due to tourism, especially in the months of January and July (MT, 2013). In a state where the rates of collection and sewage treatment are so low, even in the capital Maceió (IMA/AL, 2012), the pressure on the already fragile sanitation infrastructure seems to have a direct impact on the environmental quality of coastal waters. Figure 4 illustrates the improper monthly average of beaches monitored in five years, and the average monthly rainfall of a station located in Maceió.

\section{Conclusions}

The analysis of the environmental quality of the coast of Alagoas, focusing the coastal bathing, based on Brazilian law, at 53 monitoring stations, revealed a general trend of degradation of the water quality, although certain sections have shown improvement or variations close to stability.

Low levels of sanitation, especially sewage collection and treatment, the lack of an effective land planning and environmental development of agribusiness activities and low sustainability seems to be the main factors that negatively affect the quality of coastal waters of the state of Alagoas. According to coliforms content data, the growth in tourism and poor infrastructure, the pollutant loads to water bodies tributaries increased significantly, in recent years.

\section{Appendix}

Supporting Information associated with this article is available online at http://www.aprh.pt/rgci/pdf/rgci-562_Fontenelle_SupportingInformation.pdf

\section{References}

Alm, E.W.; Burke, J.; Spain, A., (2003) - Fecal indicator bacteria are abundant in wet sand at freshwater beaches. Water Research, 37(16):3978-3982. DOI: 10.1016/S00431354(03)00301-4

APHA-AWWA-WEF (1999) - Standard Methods for the Examination of Water and Wastewater. 20th Edition, n/p [521p.], American Public Health Association (APHA) / American Water Works Association (AWWA) / Water Environment Federation (WEF), Washington, DC. USA. Avaliable on line at http://www.mwa.co.th/download/file_upload/SMWW_1000-3000.pdf

CETESB (2010) - Qualidade das águas superficiais do Estado de São Paulo:2009. 310p., Série Relatórios CETESB (ISSN: 01034103), Companhia Ambiental do Estado de São Paulo (CETESB), São Paulo, SP, Brazil. Available on-line at http://www.cetesb.sp.gov.br/agua/aguas-superficiais/35-publicacoes-/relatorios

CETESB (2011) - Qualidade das águas superficiais do Estado de São Paulo: 2010. 298p, Série Relatórios CETESB (ISSN: 01034103), Companhia Ambiental do Estado de São Paulo (CETESB), São Paulo, SP, Brazil. Available on-line at http://www.cetesb.sp.gov.br/agua/aguas-superficiais/35-publicacoes-/relatorios

CETESB (2012) - Qualidade das águas superficiais do Estado de São Paulo: 2011. 356p., Série Relatórios CETESB (ISSN: 0103-4103), Companhia Ambiental do Estado de São Paulo (CETESB), São Paulo, SP, Brazil. Available on-line at http://www.cetesb.sp.gov.br/agua/aguas-superficiais/35-publicacoes-/relatorios

Costanza; R., d'Arge, R.; de Groot, R.; Farber S.; Grasso M.; Hannon B.; Limburg K.; Naeem S.; O’Neill R. V.; Paruelo J.; Raskin R. G.; Sutton P.; Belt M V. D.. (1997) - The value of the world's ecosystem services and natural capital. Nature (ISSN: 0028-0836), 387(6630):253-260.

Fujioka, R.(2002) - Microbial indicators of marine recreational water quality. In: Hurst, C.J., Crawford, R.L., Knudsen, G., McIneney, M.J., Stetzenbach, L.D. (Eds.), Manual of Environmental Microbiology, $2^{\text {nd }}$ ed., pp.234-243, American Society for Microbiology Press, Washington, DC, U.S.A. ISBN: 9781555813796.

Gruber, N.L.S.; Barboza, E.G.; Nicolodi, J.L. (2003) - Geografia dos Sistemas Costeiros e Oceanográficos: subsídios para gestão integrada da zona costeira. Gravel (ISSN: 1678-5975), 1:81-89, Instituto de Geociências, Universidade Federal do Rio Grande do Sul, Porto Alegre, RS, Brazil. Available on-line at http://www.ufrgs.br/gravel/1/Gravel_1_07.pdf

Guang, S.; Xu, R.; Chen, S. et al. (2002) - Development of a procedure for discriminating among Escherichia coli isolates from animal and human sources. Applied Environment Microbiology, 68(6):2690-2698. DOI: 10.1128/AEM.68.6.2690-2698.2002

IBGE (2011a). Atlas Geográfico das Zonas Costeiras e Oceânicas do Brasil. Rio de Janeiro. 176 p., Instituto Brasileiro de Geografia e Estatística (IBGE), Rio de Janeiro, RJ, Brasil. ISBN: 9788524042195.

Medeiros, J.R. (2009) - Influência das Águas da Bacia Hidrográfica Pirangi na Balneabilidade das Praias de Pirangi, nos municípios de Nísia Floresta e Parnamirim - Rio Grande do Norte, Brasil. 67p., Dissertação de mestrado, Universidade Federal do Rio Grande do Norte, Natal, RN, Brasil. Available on-line at http://repositorio.ufrn.br:8080/jspui/bitstream/123456789/18238/1/Welli ngtonSLJ_DISSERT.pdf 
Melo-Magalhães, E.M.; Medeiros, P.R.P.; Lira, M.C.A.; Koening, M.L.; Moura, A.N. (2009) - Determination of eutrophic areas in Mundaú/Manguaba lagoons, Alagoas-Brazil, through studies of the phytoplanktonic community. Brazilian Journal of Biology, 69(2):271-280. DOI: 10.1590/S1519-69842009000200006

Morais, R.C.S.; Silva, C.E. (2012) - Diagnóstico ambiental do balneário Curva São Paulo no rio Poti em Teresina, Piauí (Brasil). Engenharia Sanitária e Ambiental (ISSN: 1809-4457), 17(1):41-50, Associação Brasileira de Engenharia Sanitária e Ambiental - ABES, Rio de Janeiro, RJ, Brazil. Available on-line at http://www.scielo.br/pdf/esa/v17n1/v17n1a08.

MT (2013) - Anuário Estatístico de Turismo (ano base 2012). n/p [223p.], Anuário Estatístico vol. 40, Ministério do Turismo (MT), Brasília, DF, Brasil. Available on-line at http://www.dadosefatos.turismo.gov.br/dadosefatos/anuario/detalhe/201 3.html

Muehe, D. (org.) (2006) - Erosão e Progradação no Litoral Brasileiro. 476p., Ministério do Meio Ambiente (MMA), Brasília, DF, Brasil. ISBN 85-7738-028-9. Avaliable on line at http://www.mma.gov.br/publicacoes/gestao-territorial/category/80gestao-costeira-g-erosao-e-progradacao

Neto, J.V.F.; Santos, R.J.Q.; Wanderley, P.R.B.; Wanderley, P.R.M. (2002) -Vulnerabilidade natural das águas subterrâneas em área do Tabuleiro dos Martins, Alagoas - Brazil. Revista Águas Subterrâneas, 16:57-75. DOI: 10.14295/ras.v16i1.1300

Noble, R.T.; Moore, D.F.; Le Ecaster, M.K.; McGee, C.D.; Weisberg, S.B. (2003) - Comparison of total coliform, fecal coliform, and enterococcus bacterial indicator response for ocean recreational water quality testing. Water Research, 37(7):1637-1643. DOI: 10.1016/S0043-1354(02)00496-7

Oliveira, A.M.; Kjerfve B. (1993) - Environmental Responses of a Tropical Coastal Lagoon System to Hydrological Variability: Mundaú-Manguaba, Brazil. Estuarine, Coastal and Shelf Science, 37(6):575-591. DOI: 10.1006/ecss.1993.1074

Porfirio, Z.; Ribeiro, M.P.; Estevam, C.S.; Houly R.L.S.; Sant'Ana, A.E.G.(1999) - Hepatosplenomegaly caused by an extract of cyanobacterium Microcystis aeruginosa bloom collected in the Manguaba Lagoon, Alagoas - Brazil. Revista de Microbiologia, 30:278-285 DOI: 10.1590/S0001-37141999000300016

Ramaiah, N. (2002) - Coliform and human pathogenic bacteria in tourism affected water bodies in North Goa. Coastin, 7:13-16. National Institute of Oceanography (NIO), Dona Paula, Goa, India. Available on-line at http://drs.nio.org/drs/handle/2264/1338

Santos Filho, W.; Ferreira, I.V.L.; Barboza, M. G. (2007) - Qualidade das águas do Riacho do Silva localizado no Parque Municipal de Maceió - AL. Anais do $24^{\circ}$ Congresso Brasileiro de Engenharia Sanitária e Ambiental, Rio de Janeiro, Rio de Janeiro, Brasil.

Silva Júnior, R.I. (2009) - Evolução da Urbanização e seu Efeito no Escoamento Superficial na Bacia do Riacho Reginaldo, MACEIÓ-AL. 79p., Dissertação de mestrado, Universidade Federal de Alagoas, Maceió, Alagoas, Brazil. Available on-line at http://www.ctec.ufal.br/posgraduacao/ppgrhs/sites/default/files/dissertac aorubemizidrodasilvajunior.pdf

Solo-Gabriele, H.M.; Wolfert M.A.; Desmarais, T.R.; Palmer, C.J. (2000) - Sources of Escherichia coli in a coastal subtropical environment. Applied Environment Microbiology, 66:230-237. ISSN: 1098-5336. American Society for Microbiology. Washington, DC. U.S.A. Available on-line at http://www.ncbi.nlm.nih.gov/pmc/articles/PMC91811/

Uzoigwe, J.C.; O’Brien, E.H.; Brown, E.J. (2007) - Using nutrient utilization patterns to determine the source of Escherichia coli found in surface water. African Journal of Environmental Science Technology (ISSN: 1996-0786), 1(1):7-13, Island, Lagos, Nigeria. Available on-line at http://academicjournals.org/article/article1380104089_Uzoigwe\%20et\% 20al.pdf

Verdade L.M.; Gheler-Costa, C., Penteado M., Dotta G. (2012) The Impacts of Sugarcane Expansion on Wildlife in the State of São Paulo, Brazil. Journal of Sustainable Bioenergy Systems, 2(4):138-144 DOI: $10.4236 /$ jsbs.2012.24020

Wilkes, G.; Edge, T.; Gannon, V.; Jokinen, C.; Lyautey, E.; Medeiros, D.; Neumann, N.; Ruecker, N.; Topp, E.; Lapen, D. (2009) Seasonal relationships among indicator bacteria, pathogenic bacteria, Cryptosporidium oocysts, Giardia cysts and hydrological indices for surface waters within an agricultural landscape. Water Research, 43(8):2209-2223. DOI: 10.1016/j.watres.2009.01.033

\section{Pieces of legislation}

Resolução CONAMA n ${ }^{\circ}$ 274, de 29 de novembro de 2000 - Revisa os critérios de Balneabilidade em Águas Brasileiras. Conselho Nacional do Meio Ambiente (CONAMA), Ministério do Meio Ambiente. Published in the D.O.U. (Diário Oficial da República Federativa do Brasil), 25 January 2001, Brasília, DF, Brazil. Available http://www.mma.gov.br/port/conama/legiabre.cfm?codlegi=272

Decreto $n^{\circ} 5.300$ de 7 de dezembro de 2004 - Regulamenta a Lei ${ }^{\circ}$ 7.661, de 16 de maio de 1988, que institui o Plano Nacional de Gerenciamento Costeiro - PNGC, dispõe sobre regras de uso e ocupação da zona costeira e estabelece critérios de gestão da orla marítima, e dá outras providências. Published in the D.O.U. (Diário Ofícial da República Federativa do Brasil), 8 December 2004, Brasília, DF, Brazil. Available on-line at http://www.planalto.gov.br/ccivil_03/_ato20042006/2004/decreto/D5300.htm

\section{Internet Resources}

IBGE (2011b) - Censo Demográfico 2010: Resultados do Universo características da população e dos domicílios. [web page]. In: Sidra - sistema IBGE de recuperação automática, Instituto Brasileiro de Geografia e Estatística (IBGE), Rio de Janeiro, RJ, Brazil. http://www.sidra.ibge.gov.br/cd/cd2010universo.asp?o=5\&i=P

IBGE (2011c) - Censo 2010: Malha Digital de Setores Censitários e demais divisões político-administrativas. [web page]. In: censo_2010, setores_censitarios, Instituto Brasileiro de Geografia e Estatística (IBGE), Rio de Janeiro, RJ, Brazil. ftp:/geoftp.ibge.gov.br/malhas_digitais/censo_2010/setores_censitarios/

IMA/AL (2012) - Relatórios semanais de análise da balneabilidade. [web page]. Instituto do Meio Ambiente do Estado de Alagoas (IMA/AL), Maceió, AL, Brazil. http://www.ima.al.gov.br/balneabilidade-marco/

INMET (2012) - Banco de Dados Meteorológicos para Ensino e Pesquisa. Ministério da Agricultura, pecuária e abastecimento. [web page]. Instituto Nacional de Meteorologia (INMET), Brasília, DF, Brazil. http://www.inmet.gov.br/projetos/rede/pesquisa/

UDOP (2012) - Relação das unidades/destilarias no Brasil. [web page]. União dos Produtores de Bioenergia (UDOP), Araçatuba, SP, Brazil. http://www.udop.com.br/index.php?item=unidades 